accumulate in the $15-$ to $30-\mathrm{cm}$ depth.

Seasonal decreases in $\mathrm{NO}_{3}-\mathrm{N}$ levels were similar at both locations (Table 3). The initial lower $\mathrm{NO}_{3}-\mathrm{N}$ levels at Clayton were due to slightly lower residual levels in the soil and increased leaching from preplant irrigation.

At the Clayton location, soil $\mathrm{NO}_{3}-\mathrm{N}$ levels were about twice as high in the beds with actively growing plants as in the nonplanted beds (Table 4). Greater soil moisture levels and increased leaching in the nonplanted beds more than offset the lack of $\mathrm{N}$ uptake by the plants. A much smaller difference was observed at the Charleston location, where leaching was slightly less severe due to greater lateral water movement. More-vigorous plant growth at the Charleston location also resulted in greater $\mathrm{N}$ uptake. Nitrate- $\mathrm{N}$ distribution within the bed was also affected by the presence of plants. The absence of water uptake in the nonplanted plots resulted in constant soil moisture levels near field capacity in those areas of the bed close to the drip tubing. Consequently, $\mathrm{NO}_{3}-\mathrm{N}$ levels in the center and left side of the bed tended to be lower and more uniformly distributed than in the planted plots, where moisture levels fluctuated.

Maintaining soil moisture levels at or above $-20 \mathrm{kPa}$ resulted in lower soil $\mathrm{NO}_{3}-\mathrm{N}$ levels than maintaining soil moisture at $-30 \mathrm{kPa}$ (Table 4). Increased leaching from the additional water at the $-20 \mathrm{kPa}$ irrigation level was probably responsible for most of the additional $\mathrm{NO}_{3}-\mathrm{N}$ losses, although plant uptake may have been a factor in the planted plots. The potential for reduced BER and increased yields at relatively high soil moisture levels (higher than - $20 \mathrm{kPa}$ ) more than offsets any negative effects of increased $\mathrm{NO}_{3}-\mathrm{N}$ leaching.

\section{Literature Cited}

Bar-Yosef, B. 1977. Trickle irrigation and fertilization of tomatoes in sand dunes: Water, $\mathrm{N}$ and $\mathrm{P}$ distributions in the soil and uptake by plants. Agron. J. 69:486-491.

Bar-Yosef, B., C. Stemmers, and B. Sagir. 1980 Growth of trickle-irrigated tomato as related to rooting volume and uptake of $\mathrm{N}$ and water. Agron. J. 72:815-822.

Bresler, E, 1975. Two-dimensional transport of solutes during non-steady infiltration from a trickle source. Proc. Soil Sci. Soc. Amer. 39:604-613.

Cook, W. P., R.P. Griffin, C.E. Drye, and P.J. Rathwell. 1980. Commercial tomato production in South Carolina. Clemson Univ. Coop. Ext. Bul. 625.

Goldberg, D., B. Gornat, and Y. Bar. 1971. The distribution of roots, water and minerals as a result of trickle irrigation. J. Amer. Soc. Hort. Sci. 96:645-648.

Graetz, D. A., J.G.A. Fiskell, S.J. Locascio, and B. Zur. 1978. Chloride and bromide movement with trickle irrigation of bell peppers. Proc. Fla. State Hort. Soc. 91:319-322.

Karlen, D.L. and M.L. Robbins. 1983. Management practices for fresh-market tomato production in the Southeastern Coastal Plain. HortScience 18(5):732-734.

Karlen, D. L., C.R. Camp, and M.L. Robbins. 1985. Fresh market tomato response to $\mathrm{N}$ and $\mathrm{K}$ fertilization and water management practices.
Commun. Soil Sci. Plant Anal. 16(1):71-81.

Kenney, D.R. and D.W. Nelson. 1982. Nitrogen inorganic forms, p. 643-698. In: A.L. Page, R.H. Miller, and D.R. Keeney (eds.). Methods of soil analysis. Part 2. 2nd ed. Amer. Soc. Agron., Madison, Wisc.

Knavel, D.E. and H.C. Mohr. 1967. Distribution of roots of four different vegetables under paper and polyethylene mulches. Proc. Amer. Soc. Hort. Sci. 91:589-597.

Locascio, S. J., J.G.A. Fiskell, and F.G. Martin. 1981. Responses of bell peppers to nitrogen sources. J. Amer. Soc. Hort. Sci. 106:628-632. Persaud, N., S.J. Locascio, and C.M. Geraldson. 1976. Effect of rate and placement of nitrogen and potassium on yield of mulched tomato using different irrigation methods. Proc. Fla. State Hort. Soc. 89:135-138.

Persaud, N., S.J. Locascio, and C.M. Geraldson. 1977. Influence of fertilizer rate and placement and irrigation method on plant nutrient status, soil soluble salts and root distribution of mulched tomatoes. Soil \& Crop Sci. Soc. Fla. 35:121125

Tanaka, A., K. Fujita, and K. Kikuchi. 1974 Nutrio-physiological studies on the tomato plant. I. Outline of growth and nutrient absorption. Soil Sci. Plant Nutr. 20:57-68.

Tecator. 1985. Kjeltec System 1003 Distilling Unit. Tecator, Hoganas, Sweden.

\title{
Isolation and Characterization of a Chemical from Tomato Apices that Stimulates Plant Growth
}

\author{
Yichun Wang, Violet Wert, Muraleedharan Nair, and Stanley Ries \\ Department of Horticulture, Michigan State University, East Lansing, \\ MI 48824
}

Additional index words. plant growth regulator, shoot apex, plant hormone,

Chlamydomonas reinhardtii, Lycopersicon.esculentum

Abstract. A methanol: water extract of tomato (Lycopersion esculentum Mill.) apices increased the growth of the alga Chlamydomonas reinhardtii. The active substance from the dried shoot apices was purified by $\mathrm{C}_{18}$ flash column and high performance liquid chromatography. The purified extract enhanced the growth of tomato, corn (Zea mays L.), and rice (Oryza sativa L.) seedlings at concentrations less than $1.0 \mathrm{mg} \cdot \mathrm{liter}^{-1}$ With Chlamydomonas, the purified extract increased cell division $111 \%$ at $0.1 \mathrm{mg} \cdot \mathrm{liter}^{-1}$ and chlorophyll content $23 \%$ at $10 \mathrm{mg} \cdot \mathrm{liter}^{-1}$ in 18 hours. Nuclear magnetic resonance and mass spectroscopy indicated that the purified fraction was a mixture of compounds having sugar moieties. Analysis by thin layer chromatography showed that the fraction was ninhydrin positive and more polar than the known plant hormones studied.

Since cell division and elongation are important functions in shoot apices, they may be a source of unknown plant growth substances other than auxins, gibberellins, cytokinins, ethylene, and abscisic acid (Davies, 1987). This research was initiated to test the hypothesis that there are unknown chemicals in the shoot apex that stimulate plant growth. Since, with higher plant species, it is difficult to screen more than a few plant extracts at one time or to detect small differences because of the time required and the number of plants needed, the alga Chlamydomonas reinhardtii was used to screen the many chromatographic fractions obtained in the isolation procedure. In less than $24 \mathrm{hr}$, information could be obtained that would take at least 2 weeks with higher plants. Any compound that appeared interesting had to

Received for publication 14 Nov. 1988. Michigan Agricultural Experiment Station Journal Article no. 12890. The cost of publishing this paper was defrayed in part by the payment of page charges. Under postal regulations, this paper therefore must be hereby marked advertisement solely to indicate this fact. be screened on higher plant species before proceeding to chemical identification and practical applications.

After evaluating extracts from several plant species, including wheat (Triticum aestivum L.), cabbage (Brassica oleracea capitata L.), carrot (Daucus carota L.), rice (Oryza sativa L.), and tomato (Lycopersicon esculentum Mill.), for stimulator activity, tomato was selected for further study because of the response of the alga and the ease of obtaining plant material.

Tomato shoot apices were obtained from 25-day-old greenhouse-grown 'Ohio 7870' tomato plants. These were grown in $30 \times$ $30-\mathrm{cm}$ styrofoam flats under metal halide lights, with a photosynthetic photon flux of $425 \mu \mathrm{mol} \cdot \mathrm{s}^{-1} \cdot \mathrm{m}^{-2}$ measured at the top of the canopy. A 14-hr photoperiod was maintained with air at $\approx 28 \mathrm{C}$ day $/ 22 \mathrm{C}$ night. The plants were fertilized weekly with soluble $20 \mathrm{~N}-20 \mathrm{P}-20 \mathrm{~K}$ fertilizer $(500 \mathrm{ml} / \mathrm{flat})$ at a rate of $1.0 \mathrm{~g} \cdot$ liter $^{-1}$ water. The shoots were harvested and lyophilized at $5 \mathrm{C}$ for $24 \mathrm{hr}$. After large numbers of shoots were collected, the apices $(5-10 \mathrm{~mm})$ were removed and stored frozen in glass containers before being ground 
Table 1. Chlorophyll concentration in Chlamydomonas after $18 \mathrm{hr}$ to several concentrations of extract obtained from tomato apices by sequential extraction with various solvents.

\begin{tabular}{|c|c|c|c|c|}
\hline \multirow[b]{2}{*}{ Solvent } & \multicolumn{4}{|c|}{ Concn of extract (mg/liter) } \\
\hline & 0.1 & 1.0 & 10 & 100 \\
\hline & \multicolumn{4}{|c|}{$\mu g$ Chlorophyll/ml Chlamydomonas } \\
\hline Control & 2.23 & 2.33 & 1.98 & 2.09 \\
\hline Hexane & 2.23 & 2.39 & 2.04 & 2.25 \\
\hline Chloroform & 2.23 & 2.36 & 2.06 & 1.75 \\
\hline Methanol & 2.25 & 2.43 & 2.64 & 4.39 \\
\hline Water & 2.28 & 2.45 & 3.01 & 1.97 \\
\hline LSD $5 \%$ & NS & 0.06 & 0.12 & 0.16 \\
\hline LSD $1 \%$ & NS & 0.08 & 0.16 & 0.22 \\
\hline \multicolumn{5}{|c|}{$\begin{array}{l}\text { Table 2. Response of Chlamydomonas to known plant hormones and to the purified extract }(\mathrm{RT}= \\
12.6 \mathrm{~min} \text { ) from tomato apices in individual tests. }\end{array}$} \\
\hline \multirow{2}{*}{$\begin{array}{c}\text { Concn } \\
\left(\mathrm{mg} \cdot \text { liter }^{-1}\right)\end{array}$} & \multicolumn{4}{|c|}{$\mu \mathrm{g}$ Chlorophyll/ml Chlamydomonas } \\
\hline & $\mathrm{GA}_{3}^{2}$ & $\mathrm{IAA}^{\mathrm{y}}$ & $\mathrm{BA}^{\mathbf{y}}$ & $\mathrm{PE}^{y, x}$ \\
\hline Control & 2.19 & 2.23 & 2.25 & 1.32 \\
\hline 0.1 & 2.23 & 2.35 & 2.27 & 1.34 \\
\hline 1.0 & 2.27 & 2.29 & 2.28 & 1.37 \\
\hline 10.1 & 2.27 & 2.29 & 2.28 & $1.44^{w}$ \\
\hline 100.0 & $1.30^{\mathrm{w}}$ & $1.31^{w}$ & $2.38^{w}$ & $1.89^{w}$ \\
\hline
\end{tabular}

${ }^{ } \mathrm{F}$ value for quadratic trend of micrograms of chlorophyll with chemical concentration significant at $P$ $=0.01$.

YF value for linear trend of micrograms of chlorophyll with chemical concentration significant at $P=$ 0.01 .

$\times \mathrm{PE}=$ purified extract from tomato apices.

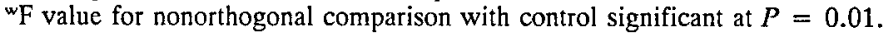

in a Wiley mill.

Lyophilized and milled shoot apices were packed in a glass column $(2: 5 \times 45.0 \mathrm{~cm})$ and extracted sequentially with hexane, chloroform, methanol, and water (Weston et al., 1987).Twenty milliliters of each solvent were used per $100 \mathrm{mg}$ of dry plant material. All fractions, except hexane, were decolorized with neutral activated charcoal (C-170; Aldrich, Milwaukee) by refluxing in methanol for $20 \mathrm{~min}(1.0 \mathrm{~g}$ charcoal $/ 400 \mathrm{mg}$ dry plant apices). The hot solution was filtered through an acid-washed celite bed, and the resulting colorless solution was evaporated to dryness and weighed. Each fraction was redissolved in the extraction solvent $(1.0 \mathrm{mg} /$ $100 \mu \mathrm{l})$.

Since most growth-promoting activity was present in the water and methanol fractions of the shoot apices, the powdered shoot apices $(6.8 \mathrm{~g})$ were ground in $200 \mathrm{ml}$ of 60 methanol : 40 water $(\mathrm{v} / \mathrm{v})$ and filtered. The colorless extract, after concentrating at reduced pressure to remove methanol, was lyophilized at 5C. Thin layer chromatography (TLC), with silica gel $\left(0.25 \mathrm{~mm}, \mathrm{~F}_{25}\right.$; Merck, Rahway, N.J.), of the crude extract ( $5 \mathrm{CHCl}_{3}$ : $1 \mathrm{MeOH}: 1 \mathrm{HCOOH}$, by volume) gave three bands (viewed at $366 \mathrm{~mm}$ ) that were collected and eluted. These fractions were bioassayed with algae and the activity expressed per unit weight of the residue.

Large-scale purification of the crude extract $(173 \mathrm{mg})$ was achieved with a flash column (35. cm long and $20 \mathrm{~mm}$ i.d.) containing $\mathrm{C}_{18}$ (particle size, $40 \mu \mathrm{m}$; Baker, Phillipsburg, N.J.), using 30 methanol :70 water $(\mathrm{v} / \mathrm{v})$ at a gel height of $18 \mathrm{~cm}$ at 2.0 $\mathrm{ml} \cdot \mathrm{min}^{-1}$. Twenty-three $5.0-\mathrm{ml}$ fractions were collected and pooled into three fractions, based on algae bioassays of TLC plates (vials 15, 6-8, and 9-23, respectively).
Fraction 2 was the most active and was further purified by HPLC using a ChemcoPak 5-ODS-H Cl $\mathrm{Cl}_{18}, 20 \times 250$-mm preparative column (Nychrom, Sunnyvale, Calif.). The isocratic solvent system used was 30 methanol :70 water $(\mathrm{v} / \mathrm{v})$, with a flow rate of 4.0 $\mathrm{ml} \cdot \mathrm{min}^{-1}$ detected at $254 \mathrm{~nm}$. The six fractions separated on HPLC were evaporated to dryness in vacuo and bioassayed with algae. The most active fraction was further purified by HPLC using 30 methanol : 70 water $(\mathrm{v} / \mathrm{v})$, with the $\mathrm{pH}$ of the mobile phase adjusted to 2 by trifluroacetic acid. This purified extract consisted of a single peak [retention time $(\mathrm{RT})=12.6$ rein] that was dried $(8.0 \mathrm{mg})$ and used for bioassays, TLC, proton nuclear magnetic resonance (H-NMR), and mass spectroscopy (MS) analysis.

Three bioassay systems were used for testing biologically active compounds extracted from tomato shoot apices. Chlamydomonas reinhardtii, a unicellular green alga, was used to monitor the growth promotion or inhibition of various fractions throughout the isolation and identification procedure, as described by Kish (1986).

Tomato ('Ohio 7870') and corn seedlings ('Pioneer 3780') were grown in 1.5-liter clay pots in a greenhouse under conditions described by Ries (1985). Foliar applications of purified extract from tomato shoot apices at concentrations of 0.01 to $10.0 \mathrm{mg} \cdot$ liter were achieved with adjustable, hand-held, aerosol sprayers (high-density, linear polyethylene; Science Products Co., Chicago). The plants were sprayed to run-off. Shoots were harvested by cutting at the soil level, dried in a forced-air oven at $70 \mathrm{C}$ for $24 \mathrm{hr}$, and weighed.

Rice (M-101, Univ. of California, Davis) was also used to evaluate growth stimulation (Ries, 1985). Six days after treatment, the plants were harvested and dried as described for corn and tomato seedlings.

A TLC comparison of the active fraction with available known plant growth substances was carried out on silica plates $(0.25$ $\mathrm{mm}, \mathrm{F}_{254}$; Merck) developed in $15 \mathrm{CHCl}_{3}$ : $5 \mathrm{MeOH}: 0.1 \mathrm{CF}_{3} \mathrm{COOH}$ (by volume). The standards used were indoleacetic acid (IAA; Calbiochem, Los Angeles), gibberellic acid (GA $;$; Velsicol, Chicago), zeatin (Sigma, St. Louis), and benzylaminopurine (BA) and kinetin (Aldrich, Milwaukee).

All experiments were conducted as randomized complete-block designs, with three blocks for the algae tests and six for the higher-plant bioassays. The observable variance due to plant sizes was assigned to blocks during the plant thinning and sorting procedure. All treatments were randomized within blocks using a random-number-table. Analysis of variance was conducted, and the means were separated using LSD when the F test was significant. Orthogonal and nonorthogonal $\mathrm{F}$ tests with single degrees of freedom were made where appropriate.

Methanol and water extracts of apices gave the most stimulator activity, as measured by the promotion of algal growth after $18 \mathrm{hr}$ (Table 1). Thus, a 60 methanol :40 water (v/v) mixture was used for further studies. This extract increased algal growth $26 \%$ at $1.0 \mathrm{mg} \cdot 1$ iter $^{-1}$ and completely inhibited growth at $100 \mathrm{mg} \cdot$ liter $^{-1}$, as measured by total chlorophyll. (The F values for differences from control were significant at $P=$ 0.01 .) There are at least two possible explanations. First, the concentration of one or more of the chemicals may have been supraoptimal, low doses stimulating and high doses inhibiting growth (Takahashi, 1986). Second, the extract may contain both inhibitors and promoters of algae growth.

Fraction 2, from the $\mathrm{C}_{18}$ flash-column purification, was resolved into six peaks by HPLC. The eluate, with a retention time of 12.6 rein, increased the growth of algae $98 \%$ at $\approx 5.0 \mathrm{mg} \cdot$ liter $^{-1}$. (LSD for difference significant at $P=0.01$. ) The $\mathrm{pH}$ of this purified extract was 6.36. H-NMR $(250 \mathrm{MHz}$, in $\mathrm{CD}_{3} \mathrm{OD}$ ) of the purified extract indicated that it was a mixture containing sugar moieties. The doublet at $5.4 \mathrm{ppm}$ was assigned to the anomeric proton of a hexose, and the signals between 3.0 to $4.5 \mathrm{ppm}$ suggested the $\mathrm{CH}$ of the sugars and, possibiy, a $\mathrm{CH}$ attached to a nitrogen moiety. There were no signals in the down-field region beyond 5.4 ppm, which confirmed the absence of olefinic, aromatic, and other IAA- and BA-type conjugates. This evidence is in agreement with the earlier TLC analyses. The active fraction on TLC separated into four components that. were positive with ninhydrin spray reagent, an indication of amino sugars, amino acids, or both. Mass spectral analysis (CI, $\mathrm{CH}_{4}$ gas) of the active fraction gave four peaks in the total ion current chromatogram (TIC), and the respective molecular ions were at $\mathrm{m} / \mathrm{z} 163 ; 218,424$, and 453 . TIC of MS was in agreement with the TLC and H-NMR of the HPLC fraction.

Another algal bioassay revealed that, as 


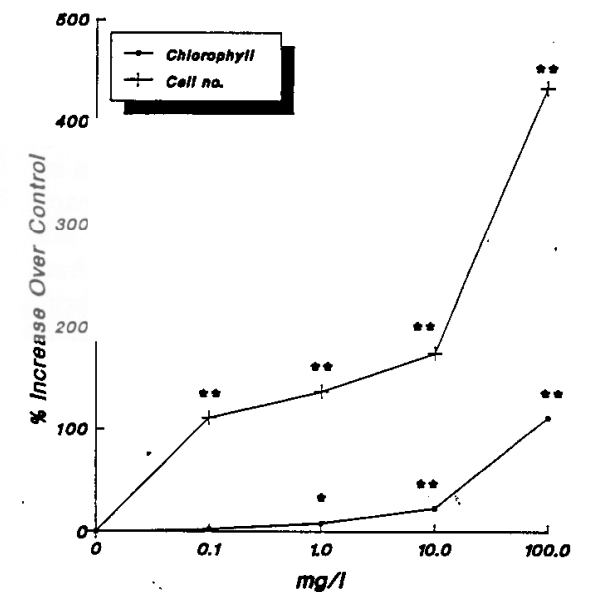

Fig. 1. Effect of HPLC purified extract (RT = 12.6 rein) from tomato shoot apices on cell number and chlorophyll content of Chlamydomonas. The cell number and chlorophyll content for the control were $8.8 \times 10^{5}$ cells $/ \mathrm{ml}$ and $1.33 \mu \mathrm{g} \cdot \mathrm{ml}^{-1}$ respectively. The $\mathrm{F}$ value for the linear trend with concentration for both chlorophyll concentration and cell number was significant at $P=0.01$

*.**LSD was significantly different from control at $P=0.05$ and 0.01 , respectively.

the concentration of the purified extract (RT $=12.6$ ) increased, the chlorophyll content and cell density of Chlamydomonas cultures increased (Fig. 1). Cell density was responsive to much-lower concentrations of purified extract than was chlorophyll content. At $100 \mathrm{mg} \cdot \mathrm{liter}^{-1}$, the purified extract increased cell division $433 \%$ and chlorophyll content $111^{\prime} \%$ in $18 \mathrm{hr}$. Clearly, cell division was affected at lower concentrations more than chlorophyll content.

None of the known plant hormones that were tested significantly increased the growth of algae (Table 2) at 0.1 to $10.0 \mathrm{mg} \cdot$ liter $^{-1}$,

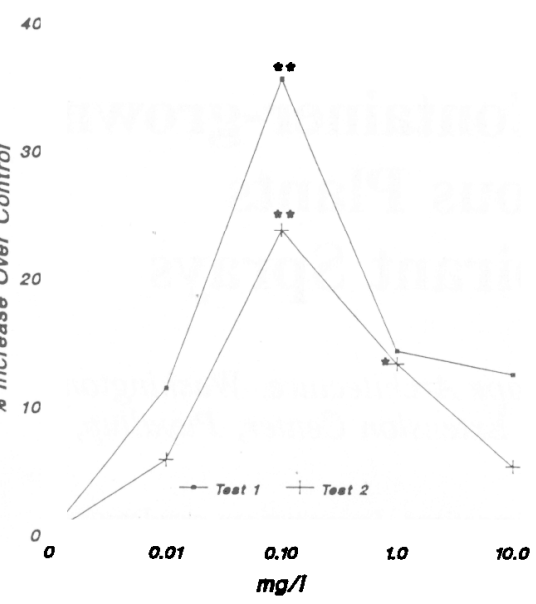

Fig. 2. Increase in dry weight over control of 29-day-old tomatoes 10 days after application of various concentrations of the purified extract $(\mathrm{RT}=12.6$ rein $)$ from tomato apices. At the end of Tests 1 and 2, the control plants weighed $1.74 \mathrm{~g}$ and $2.02 \mathrm{~g}$, respectively. The $\mathrm{F}$ value for the quadratic trend with increased concentration was significant at $P=0.01$ for both tests.

***Significantly different from control at $P=$ 0.05 snd 0.01 , respectively.

as measured by chlorophyll content. However, GA and IAA decreased the chlorophyl content of algae at concentrations of 100 $\mathrm{mg} \cdot \mathrm{liter}^{-1}$. BA increased the chlorophyll content of algae $6 \%$ at concentrations of 100 $\mathrm{mg} \cdot \mathrm{liter}^{-1}$. The extract from tomato apices increased the chlorophyll content $9 \%$ and $43 \%$ more than control at 10 and $100 \mathrm{mg} \cdot$ liter $^{-1}$ respectively. Other tests using the same algal assay, up to $10 \mathrm{mg} \cdot$ liter $^{-1}$, have shown that $\mathrm{GA}^{3}, \mathrm{ABA}$, kinetin, IAA, ethylene (ethephon), and glucose did not increase the chlorophyll content of algae (unpublished data).

The purified extract was applied in two greenhouse studies to the same tomato cultivar from which it was obtained. In both studies, there was a significant quadratic response, as measured by dry weight increases (Fig. 2); such a response is typical of many plant growth substances (Takahashi, 1986). The optimum purified extract concentration for increasing tomato growth was 0.1 $\mathrm{mg} \cdot \mathrm{liter}^{-1}$, rather than $100 \mathrm{mg} \cdot \mathrm{liter}^{-1}$, as for algae (Fig. 2).

The purified extract had increased the growth (dry weight) of 18-day-old rice and 14-day-old corn seedlings by 6 and 8 days after treatment, respectively, at $<1.0$ $\mathrm{mg} \cdot \operatorname{liter}^{-1}(\mathrm{~F}$ value for linear trend of dry weight with concentration significant at $P=$ 0.01). Thus, the extract affected the growth of alga, and monocotyledonous (corn and rice) and dicotyledonous (tomato) species and confirmed the presence of a possibly unknown endogenous plant growth substance in tomato apices.

\section{Literature Cited}

Davies, P.J. 1987. Introduction, p. 1-12. P.J. Davies (cd.). Plant hormones and their role in plant growth and development. Nijhoff, Boston

Kish, T.E. 1986. Response of Chlamydomonas reinhardtii and several vegetable crops to triacontanol and a messenger(s) elicited by triacontanol. MS Thesis, Michigan State Univ., East Lansing.

Ries, S.K. 1985. Regulation of plant growth with triacontanol. CRC Critical Rev. Plant Sci. 2:239285.

Takahashi, N. 1986. Chemistry of plant hormones. CRC Press, Boca Raton, Fla.

Weston, L. A., B.A. Burke, and A.R. Putnam. 1987. Isolation, characterization and activity of phytotoxic compounds from quackgrass [Agropyron repens (L.) Beauv.]. J. Chem. Ecol. 13:403-421. 